\title{
Climate of Bangladesh: An Analysis of Northwestern and Southwestern Part Using High Resolution Atmosphere-Ocean General Circulation Model (AOGCM)
}

\author{
M. A. Rouf ${ }^{1 *}$, M. K. Uddin ${ }^{1}$, S. K. Debsarma ${ }^{2}$ and M. Mizanur Rahman ${ }^{2}$ \\ ${ }^{1}$ Department of Environmental Science, Jahangirnagar University, Savar, Dhaka, Bangladesh \\ ${ }^{2}$ SAARC Meteorological Research Centre (SMRC), Agargaon, Dhaka-1207, Bangladesh \\ ${ }^{*}$ Corresponding author and Email: rouf63@yahoo.com
}

Received: 15 September $2011 \quad$ Accepted: 26 November 2011

\begin{abstract}
The past, present and future climatic pattern (temperature and rainfall) of northwestern and southwestern part of Bangladesh was assessed based on the High Resolution Atmospheric-Ocean General Circulation Model (AOGCM) using the present rainfall and temperature data of the Bangladesh Meteorological Department (BMD). Climatology in Bangladesh is derived from $20 \mathrm{~km}$ mesh MRI-AGCM (Atmospheric General Circulation Model) calibrated with reference to the observed data for the period of 1979-2006. Then, projections for rainfall and temperature are made for near future (2015-2034) and future (2075-99). Two disaster prone areas (i) northwestern part (Shapahar \& Porsha) and (ii) southwestern part (Kalapara \& Amtoli) were selected as the study areas. AOGCM model was run for Bangladesh and also for study areas separately. The present mean temperature for Bangladesh was found to rise from the past, rises slightly, but in near future and future the rate of mean temperature rise is projected to be much more than the present rate (increase up to $4.34{ }^{\circ} \mathrm{C} / 100$ years), the rate is projected to be $5.39{ }^{\circ} \mathrm{C} / 100$ years in case of Shapahar and Porsha a while $4.37{ }^{\circ} \mathrm{C} / 100$ years in case of Kalapara and Amtoli. The present, near future and future average rainfall of Bangladesh appeared to fluctuate, but have shown a decreasing trend (decreases up to $1.96 \mathrm{~mm} / 100$ years). The mean average rainfall of Shapahar and Porsha presently decreases very slowly (not significant), but in near future and future will decrease slowly $(0.66 \mathrm{~mm} / 100$ years $)$. In case of Kalapara, the average rainfall appears to decrease presently, near future and future will decrease up to $3.62 \mathrm{~mm} / 100$ years. The average rainfall of Amtoli appears to decrease @ 1.92mm/100 years but in near future appears to increase slightly and again decrease @ 3.27mm/100years in future.
\end{abstract}

Keywords: Atmosphere-Ocean General Circulation Model (AOGCM), climatology, simulation, temperature, rainfall

\section{Introduction}

Global warming is an important issue, with a variety of its influences on agriculture, water, health and economy. It is now recognized that climate variability and extreme events affect society more than changes in the mean climate (IPCC, 2001). Human induced changes in the global climate and associated sea level rise are widely accepted by policy makers and scientists. The Intergovernmental Panel on Climate Change (IPCC) concluded that the balance of evidence suggests a discernible human influence on global climate (IPCC, 2007). The exact magnitude of the changes in the global climate is still uncertain and subject of worldwide scientific studies. It is broadly recognized that Bangladesh is more vulnerable to these changes. Indeed, it has 
internationally been argued that Bangladesh, as a country, may suffer most severe impacts of climate change. Bangladesh is highly vulnerable because it is a low-lying country located in the deltaic plain of the Ganges, the Brahmaputra and the Meghna and is also densely populated. Its national economy mainly depends on agriculture and natural resources that are sensitive to climate change and sea level rise. The impact of higher temperature and more extreme weather events such as floods, cyclones, severe droughts and sea level rise are already being felt in South Asia and will continue to intensify (Huq et al., 1998; Ali, 1999). In this connection proper planning and sensible management of water resources are essential for this region. Long term planning is not possible without any idea of the change of climate that will be happening in future. Climate models are the main tools available for developing projections of climate change in the future (Houghton et al., 2001). A little work is done on climate change scenarios for Bangladesh using regional climate model (Islam, 2009). Despite continuous model development, Atmospheric General Circulation Models (AGCMs) still have systematic biases in simulating the East Asian summer monsoon such as an underestimate of precipitation amount over the western Pacific (Kang et al., 2002) and inappropriate temporal characteristics between precipitation and underlying sea surface temperature (Wang and Ho, 2002). Recently, a very high resolution AOGCM with the horizontal grid size of about $20 \mathrm{~km}$ developed by the Meteorological Research Institute (MRI)/Japan Meteorological Agency (JMA) is used in climate change studies (Mizuta et al., 2006) and it is beeing used for climate change projection under increases in atmospheric concentrations of greenhouse gases and aerosols (Kusunoki et al., 2006; Oouchi et al., 2006). The grid size of this model is several times smaller than that was previously used in climate model simulations. The global $20 \mathrm{~km}$ model is a unique one in terms of the horizontal resolution as well as its application to long term integration for global change studies. Due to the very high horizontal resolution, the model has more realistic representation of land-sea distribution and topography with elevated orography than other GCMs have ever had, so it is expected to have an ability to simulate rainfall and temperature more effectively over this region. This opportunity is employed for the first time in climate change scenario development for Bangladesh.

In this paper, past, present, near future and future changes in rainfall and temperature in Bangladesh especially in the northwestern and southwestern parts of Bangladesh derived from $20 \mathrm{~km}$ mesh MRI-AGCM was calibrated with reference to the observed data for the period of 1979-2006. Then, projections for rainfall and temperature are made for near future (20152034) and future (2075-2099) in Bangladesh.

\section{Model, Experimental design and Methodology}

\subsection{Model description}

The atmosphere-Ocean GCM (AOGCM) used here is a global hydrostatic fully coupled atmosphere-ocean general circulation model developed by the Meteorological Research Institute (MRI) and Japan Meteorological Agency (JMA) and a part of next generation climate model for long-term climate simulation. The simulations were performed at a triangular truncation 959 with linear Gaussian grid $\left(\mathrm{T}_{\mathrm{L}}\right.$ 959) in the horizontal in which the transform grid uses $1920 \times 960$ grid cells, corresponding to a grid size of about $20 \mathrm{~km}$. The model has 60 layers in the vertical with the model top at 0.1 $\mathrm{hPa}$. For the cumulus parameterization, the Arakawa-Schubert scheme with prognostic closure is used (Randall and Pan, 1993).

\subsection{Experimental design}

High horizontal resolution AGCM experiments were conducted using the time-slice method (Bengtsson et al., 1996; IPCC 2001), which is a two-tier global warming projection using an atmosphere-ocean coupled general circulation model (AOGCM) and an AGCM with horizontal resolution higher than that of the atmospheric part of the AOGCM. 


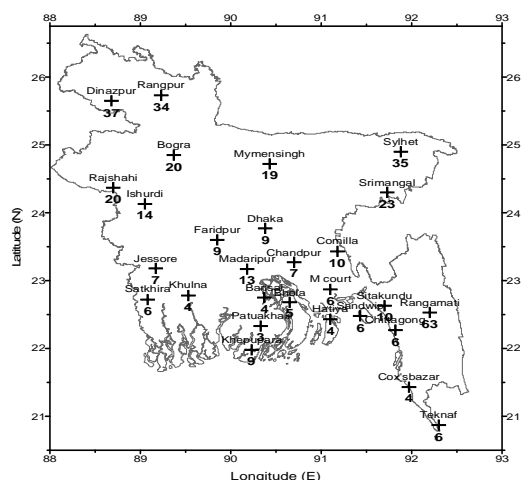

Fig. 1. BMD rain-gauge stations (plus marks) and their elevation in meters (below plus marks) for the sea level.

For present-day climate simulation, observed historical sea surface temperature (SST) by HadISST1 (Rayner et al., 2003) are prescribed for the model from 1979 to 2006 (29 years). For the near future climate simulation from 2015 to 2039 (25 years) and the end of $21^{\text {th }}$ century climate simulation from 2075 to 2099 (25 years), changes in the Multi-Model Ensemble (MME) of SSTs projected by AOGCMs of Coupled Model Inter comparison Project 3 (CMIP3) are superposed to the detrended observed historical SST. Changes in MME of SSTs are evaluated by the difference between the $20^{\text {th }}$ century simulations and future simulation of IPCC A1B emission scenario. Linear trend for future climate by AOGCMs are taken into account. These settings are applied to each grid point and to each month. Details are found in Mizuta et al., 2006.

The Intergovernmental Panel on Climate Change (IPCC) Special Report on Emission Scenarios (SRES) A1B emission scenario (IPCC, 2000) was assumed for future climate simulations. The A1B scenario is an intermediate emission scenario characterized by a future world of very rapid economic growth, global population that peaks in the middle of the $21^{\text {st }}$ Century and declines thereafter, and by a balanced introduction of new and more efficient technologies of all energy supply (IPCC, 2000; IPCC, 2001). From around 2080 to 2099, with the concentration of $\mathrm{CO}_{2}$ nearly doubled relative to that at the end of $20^{\text {th }}$ Century, the global mean surface air temperature increases by about 2.2 degrees Celsius.

\subsection{Methodology}

Observational data of Bangladesh Meteorological Department (BMD) has been utilized for validation of MRI-AOGCM generated rainfall and temperature. The BMD observation network density is low, in some cases observation sites are located about $25 \mathrm{~km}$ apart, whereas these are about $145 \mathrm{~km}$ apart in some other areas (Fig. 1). A number of grids are found which do not contain any observation site when the whole Bangladesh is gridded at $20 \mathrm{~km}$ by $20 \mathrm{~km}$ in the model resolution. Since, it is important to find out the appropriate calibration method for the application of MRIAOGCM for climate change impact studies in Bangladesh, analyses have been performed on point-to-point basis. In this procedure, observed data at a particular site is considered as being the representative for that location (Islam and Uyeda, 2007). Grid value of the model data is compared with the observed data representing that grid. If more than one observation site exist within a grid, the average value of all the observational sites is considered as representative value for that grid. Daily rain-gauge rainfall and temperature data collected by BMD are processed to obtain monthly, seasonal and annual values. The model simulated rainfall and temperature data are extracted through GrADS for 28 sites of BMD (point value) and then are converted into monthly, seasonal and annual values which are then averaged to obtain country average. The regression equation, slopes and constants are assigned from model and observed rainfall for the base line period. Estimated rainfall is obtained from model generated scenarios with the help of slopes and constants. This estimated rainfall is useful for validation of MRI-AOGCM in Bangladesh. Similarly, calibration and validation is completed for mean temperature in Bangladesh.

Two disaster prone areas, one in north-western part and another one in south-western part of Bangladesh have been selected for the present study. Shapahar and Porsha are under Noagaon district (northwestern part); Kalapara and Amtoli are under Patuakhali and Barguna districts, respectively (southwestern part). A reconnaissance field visit had been conducted to know the impact of climate change on the livelihood of small scale farmer. 


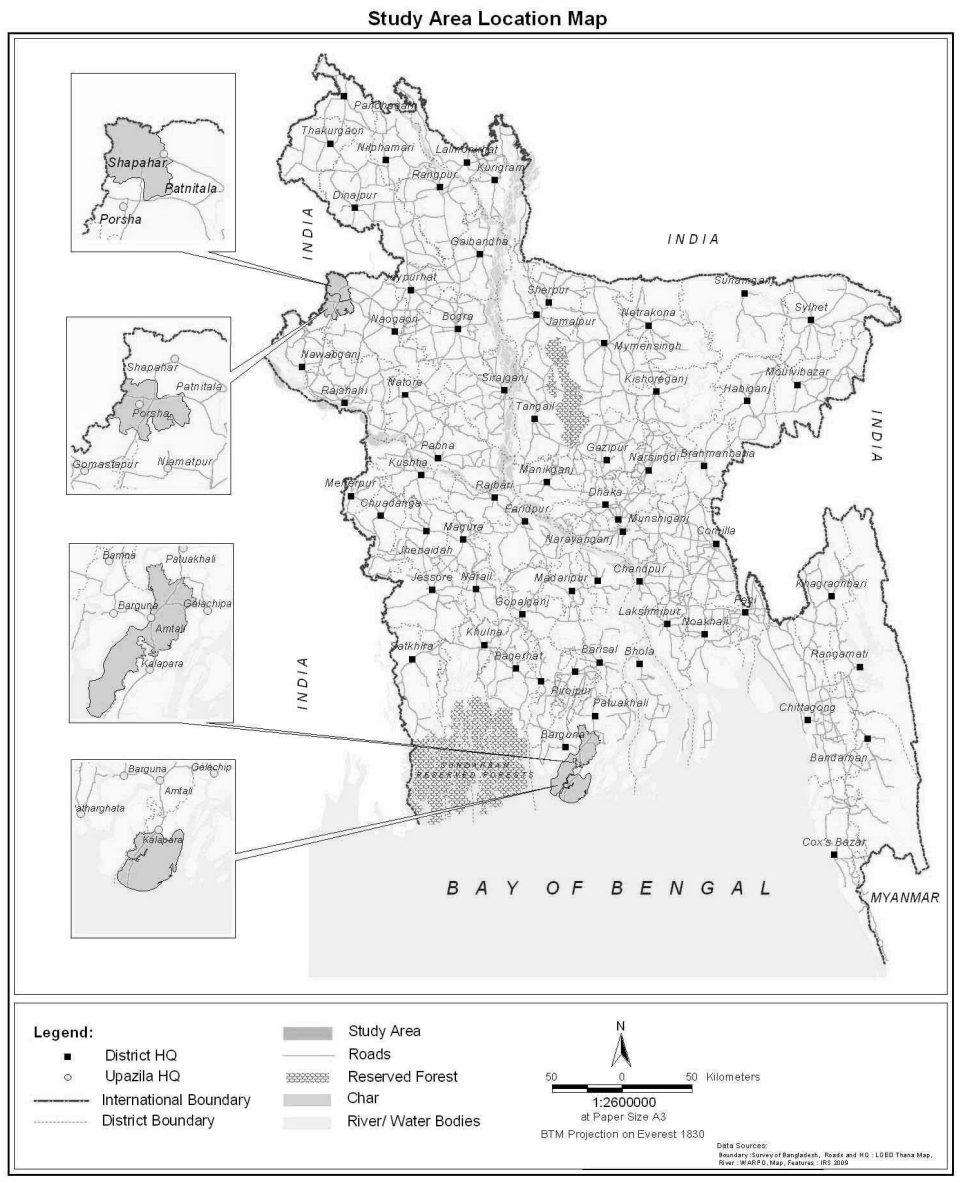

Fig . 2 . Location of study areas in the Bangladesh map.

To know the near future and future climatology of those study area, we ran the present data in AOGCM model with BMD`s present data.

\section{Results and Discussion}

\subsection{Temperature}

Present Mean Temperature, Near Future Mean Temperature and Future Mean Temperature of Bangladesh and those of the two study areas were already analyzed from AOGCM. Present Temperature has shown an increasing trend, but in future the rate of increment will be higher than the present.

\subsubsection{Present mean temperature}

During 1979-2006, mean temperature of northwestern part (Shapahar and Porsha) showed slightly increasing trend (increase up to 0.7 ${ }^{\circ} \mathrm{C} / 100$ years). Mean temperature has reached its maximum of $24.4{ }^{\circ} \mathrm{C}$ in the year 1987 . The lowest pick of mean temperature was $22.6{ }^{\circ} \mathrm{C}$ in the year 1993 . $\mathrm{R}^{2}$ value of 0.0145 indicates no significant increase of present mean temperature (Fig. 3a).

In case of southwestern part, present mean temperature showed slightly increasing trend (increases up to $0.7{ }^{\circ} \mathrm{C} / 100$ years). The mean 
temperature of Kalapara reached its maximum $23.6^{\circ} \mathrm{C}$ in the year 1987 and the lowest $\left(22.3^{\circ} \mathrm{C}\right)$ in the year 1992. The mean temperature of Amtoli reached its maximum $\left(23.12{ }^{\circ} \mathrm{C}\right)$ in the year 1987 and the lowest $\left(21.80{ }^{\circ} \mathrm{C}\right)$ in the year 1992. $\mathrm{R}^{2}$ values for Kalapara and Amtoli were 0.0266 and 0.0396 , respectively which indicates no significant increase of present mean temperature (Fig. 3b \& 3c).

(a)

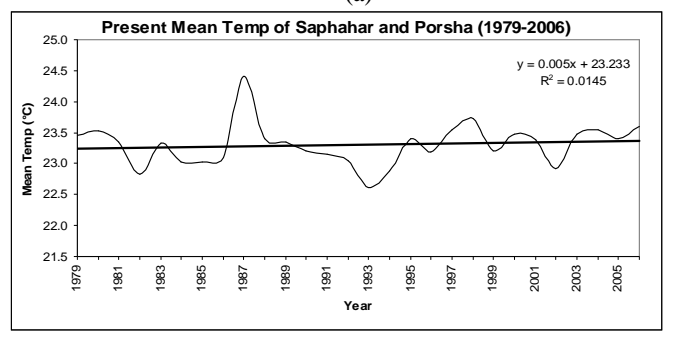

(c)

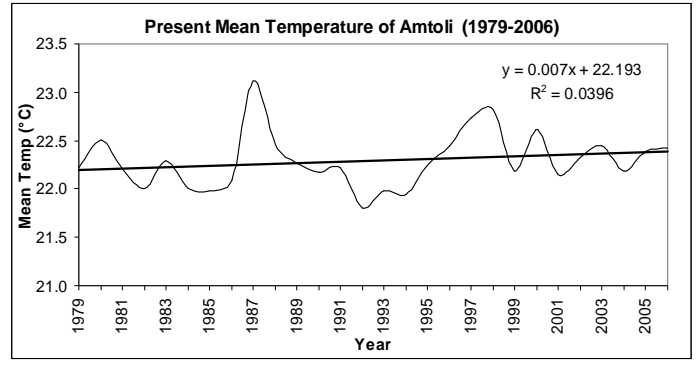

Present mean temperature of Bangladesh showed slightly increasing trend $\left(0.85{ }^{\circ} \mathrm{C} / 100\right.$ years $)$. The mean temperature reached its maximum $\left(24.9^{\circ} \mathrm{C}\right)$ in the year 1987 while the lowest $(23.6$ ${ }^{\circ} \mathrm{C}$ ) in the year 1994. $\mathrm{R}^{2}$ value of 0.0654 indicates no significant increase of present mean temperature (Fig. 3d).

(b)

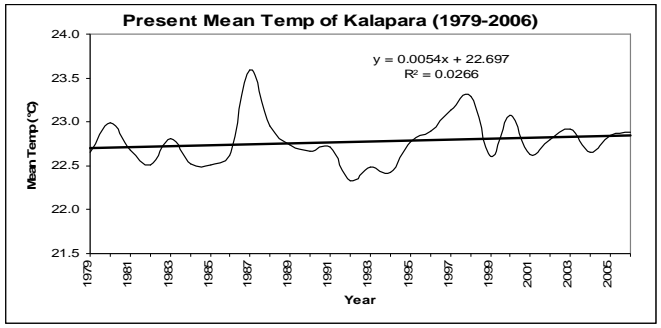

(d)

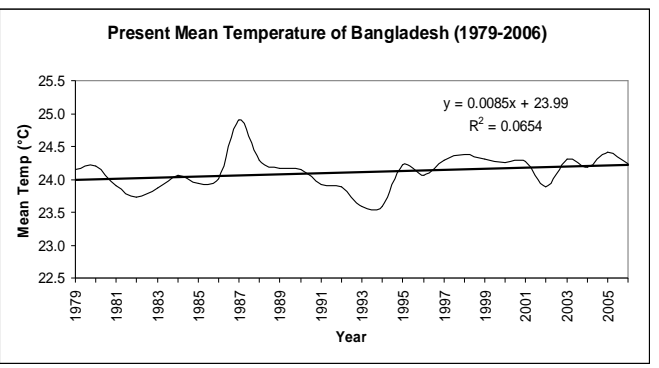

Fig. 3. Present mean temperature (1979-2006) of (a) Shapahar and Porsha, (b) Kalapara, (c) Amtoli, and (d) overall Bangladesh.

\subsubsection{Near future mean temperature}

In near future (2015-2034), the mean temperature of Shapahar and Porsha shows significantly increasing trend $\left(5.39{ }^{\circ} \mathrm{C} / 100\right.$ years). Mean temperature reaches its maximum of $24.85^{\circ} \mathrm{C}$ in the year 2032 . The lowest pick of mean temperature is $23.15^{\circ} \mathrm{C}$ in the year 2019 . $\mathrm{R}^{2}$ Value is 0.4008 which indicates significant increase of near future mean temperature in the northwestern part of Bangladesh (Fig. 4a).

Near future mean temperature of Kalapara shows increasing trend (increases up to $4.37{ }^{\circ} \mathrm{C} / 100$ years). Mean temperature of Kalapara reaches its maximum of $24.55{ }^{\circ} \mathrm{C}$ in the year 2034 and the lowest pick of mean temperature is $22.77{ }^{\circ} \mathrm{C}$ in the year 2019 . $R^{2}$ value is 0.3143 which indicates significant increase of near future mean temperature of Kalapara (Fig. 4b). During 20152034, mean temperature of Amtoli shows significantly increasing trend $\left(4.04{ }^{\circ} \mathrm{C} / 100\right.$ years). Mean temperature reaches its maximum of $24.11^{\circ} \mathrm{C}$ in the year 2034 . The lowest pick of mean temperature is $22.26{ }^{\circ} \mathrm{C}$ in the year 2019 . $R^{2}$ value is 0.283 which indicates significant increase of near future mean temperature of Amtoli (Fig. 4c). 
(a)

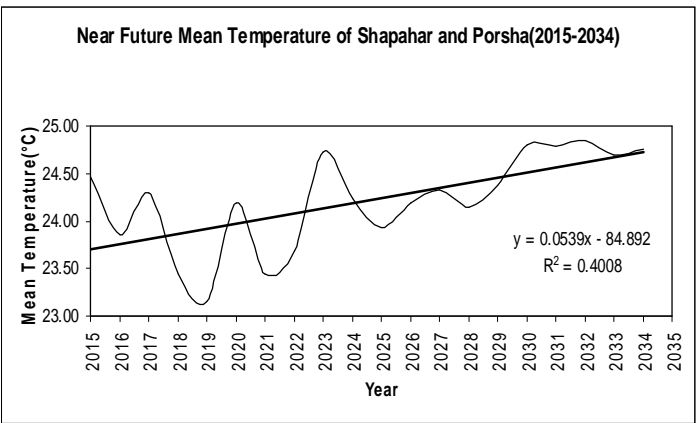

(c)

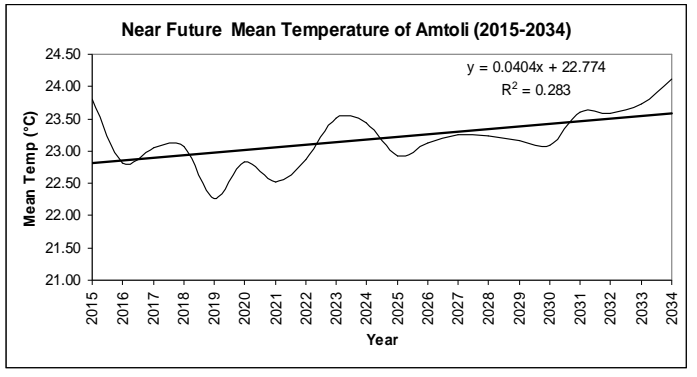

(b)

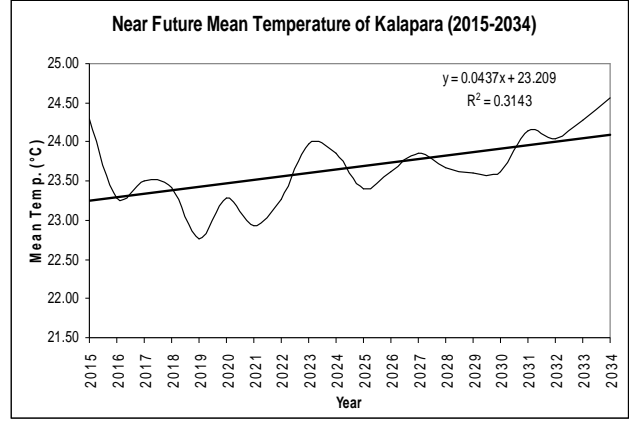

(d)

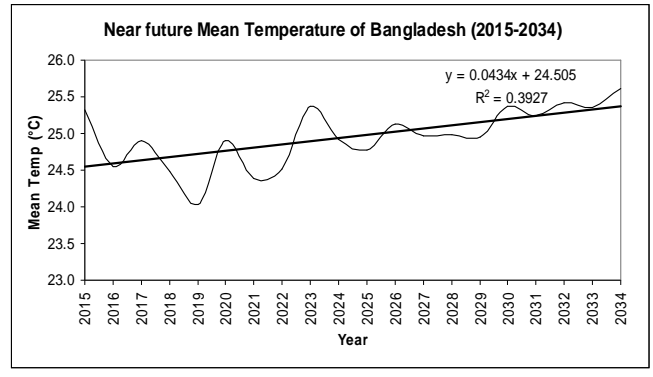

Fig. 4. Near future mean temperature of (a) Shapahar and Porsha, (b) Kalapara, (c) Amtoli, and (d) overall Bangladesh.

The mean temperature of overall Bangladesh in near future (2015-2034) shows significantly increasing trend $\left(4.34{ }^{\circ} \mathrm{C} / 100\right.$ years $)$. Mean temperature reaches its maximum of $25.6{ }^{\circ} \mathrm{C}$ in the year 2034. The lowest pick of mean temperature is $24{ }^{\circ} \mathrm{C}$ in the year 2019 . $\mathrm{R}^{2}$ value is 0.3927 which indicates significant increase in near future mean temperature of overall Bangladesh (Fig. 4d).

\subsubsection{Future mean temperature}

During 2075-2099, the mean temperature of northwestern part (Shapahar and Porsha) shows increasing trend $\left(3.58{ }^{\circ} \mathrm{C} / 100\right.$ years $)$. Mean temperature reaches its maximum of $26.58{ }^{\circ} \mathrm{C}$ in the year 2099. The lowest pick of mean temperature is $24.92{ }^{\circ} \mathrm{C}$ in the year $2080 . \mathrm{R}^{2}$
Value is 0.3749 which indicates significant increase of future mean temperature (Fig. 5a).

In case of south-western part, future mean temperature shows increasing trend (increases up to $2.52{ }^{\circ} \mathrm{C} / 100$ years). Future mean temperature of Kalapara reaches its maximum of $26.08{ }^{\circ} \mathrm{C}$ in the year 2099 and the lowest pick of mean temperature is $24.55{ }^{\circ} \mathrm{C}$ in the year 2080. Future mean temperature of Amtoli reaches its maximum of $25.69{ }^{\circ} \mathrm{C}$ in the year 2094 and the lowest pick of mean temperature is $24.15{ }^{\circ} \mathrm{C}$ in the year 2080. $\mathrm{R}^{2}$ value for Kalapara is 0.1996 which indicates no significant increase whereas that for Amtoli is 0.2104 which indicates significant increase of present mean temperature (Fig. 5b \& 5c). 
(a)

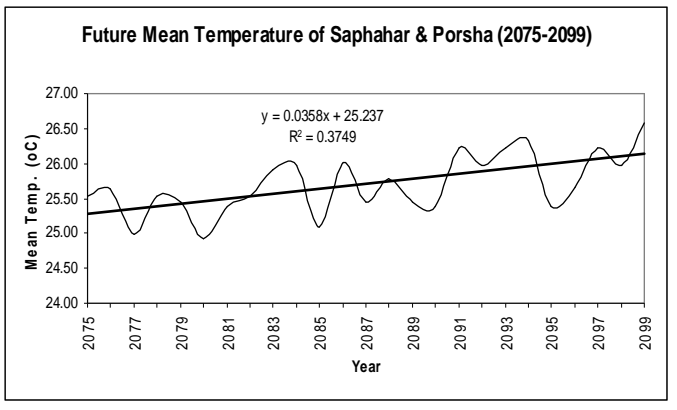

(c)

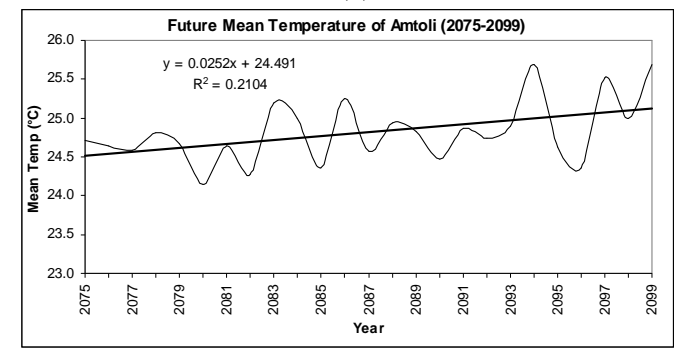

(b)

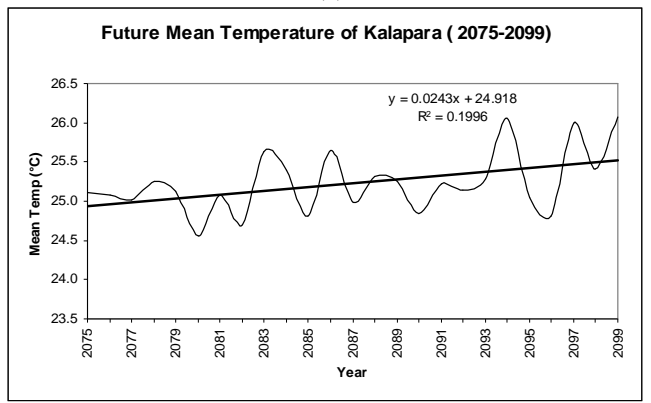

(d)

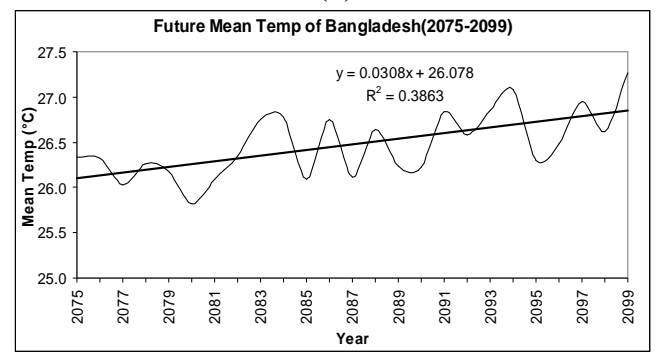

Fig. 5. Future mean temperature of (a) Shapahar and Porsha, (b) Kalapara, (c) Amtoli, and (d) overall Bangladesh.

Regression equations and corresponding $\mathrm{R}^{2}$ values of temperature situations of the study area are given in the Table-1 below:

Table1. Regression equations and $\mathrm{R}^{2}$ values of Temperature situations of the study area at a glance.

\begin{tabular}{lllll}
\hline \multicolumn{1}{c}{ Period } & \multicolumn{1}{c}{ Region } & \multicolumn{1}{c}{ Study Area } & \multicolumn{1}{c}{ Regression Equation } & R $^{2}$ Value \\
\hline Present & North West (NW) & Shapahar \& Porsha* & $\mathrm{Y}=0.005 \mathrm{x}+23.233$ & 0.0145 \\
& South West (SW) & Kolapara & $\mathrm{Y}=0.0054 \mathrm{x}+22.697$ & 0.0266 \\
& & Amtoli & $\mathrm{Y}=0.007 \mathrm{x}+22.193$ & 0.0396 \\
& & $\mathrm{Y}=0.0085 \mathrm{x}+23.99$ & 0.0654 \\
\hline \multirow{2}{*}{ Near Future } & North West (NW) & Shapahar \& Porsha* & $\mathrm{Y}=0.0539 \mathrm{x}-84.892$ & 0.4008 \\
& South West (SW) & Kolapara & $\mathrm{Y}=0.0437 \mathrm{x}+23.209$ & 0.3143 \\
& & Amtoli & $\mathrm{Y}=0.0404 \mathrm{x}+22.774$ & 0.283 \\
& Overall Bangladesh & & $\mathrm{Y}=0.0434 \mathrm{x}+24.505$ & 0.3927 \\
\hline Future & North West (NW) & Shapahar \& Porsha* & $\mathrm{Y}=0.0358 \mathrm{x}+25.237$ & 0.3749 \\
& South West (SW) & Kolapara & $\mathrm{Y}=0.0243 \mathrm{x}+24.918$ & 0.1996 \\
& & Amtoli & $\mathrm{Y}=0.0252 \mathrm{x}+24.491$ & 0.2104 \\
& & & $\mathrm{Y}=0.0308 \mathrm{x}+26.078$ & 0.3863 \\
\hline
\end{tabular}

\footnotetext{
* Regression equation \& $\mathrm{R}^{2}$ Value of Shapahar \& Porsa are same as they are in same grid
} 
Future mean temperature of Bangladesh shows increasing trend $\left(3.08{ }^{\circ} \mathrm{C} / 100\right.$ years). Mean temperature reaches its maximum $\left(27.3{ }^{\circ} \mathrm{C}\right)$ in the year 2099. The lowest pick of mean temperature will be $25.8{ }^{\circ} \mathrm{C}$ in the year $2080 . \mathrm{R}^{2}$ value is 0.3863 which indicates significant increase of present mean temperature (Fig. 5d).

\subsection{Rainfall}

The average rainfall during the present, near future and future rainfall of Bangladesh and of the two study areas were analyzed from AOGCM. Overall present rainfall is slightly decreasing, but in future decreasing rate will be higher than the present. Findings of average present rainfall, average near future rainfall and average future rainfall are as follows:

\subsubsection{Present average rainfall}

During 1979-2006, the average rainfall of northwestern part (Shapahar and Porsha) shows a slightly decreasing trend $(0.3 \mathrm{~mm} / 100$ years $)$, the highest $(5.50 \mathrm{~mm} /$ day $)$ in the year 1997 and the lowest $\left(3.80 \mathrm{~mm} /\right.$ day) in the year $1994 . \mathrm{R}^{2}$ value

(a)

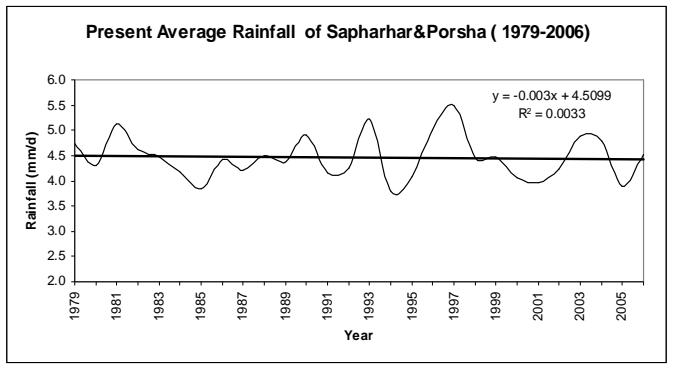

(c)

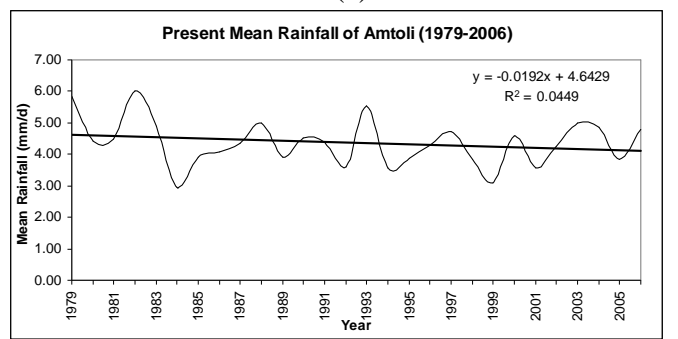

of 0.0033 indicates no significant decrease of average rainfall (Fig. 6a).

In case of south-western part, present average rainfall shows a decreasing trend (decreases up to $2.2 \mathrm{~mm} / 100$ years). The highest average rainfall of Kalapara is $6.95 \mathrm{~mm} /$ day in the year 1982 and the lowest average rainfall is $3 \mathrm{~mm} /$ day in the year 1984. The highest average rainfall of Amtoli is $6.03 \mathrm{~mm} /$ day in the year 1982 and the lowest is 2.94 in the year $1984 . \mathrm{R}^{2}$ values are 0.0378 and 0.0449 respectively which indicate no significant decrease of present average rainfall (Fig. 6b \& 6c).

Present average rainfall of Bangladesh shows slightly decreasing trend $(1.96 \mathrm{~mm} / 100$ years $)$. The highest average rainfall is $6.1 \mathrm{~mm} /$ day in the year 1979. The lowest average rainfall is 3.6 in the year 1984 . $\mathrm{R}^{2}$ value is 0.0848 which indicates no significant decrease of average rainfall (Fig. 6d).

(b)

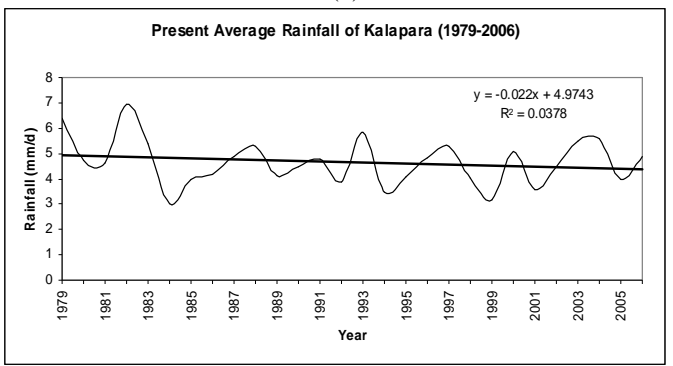

(d)

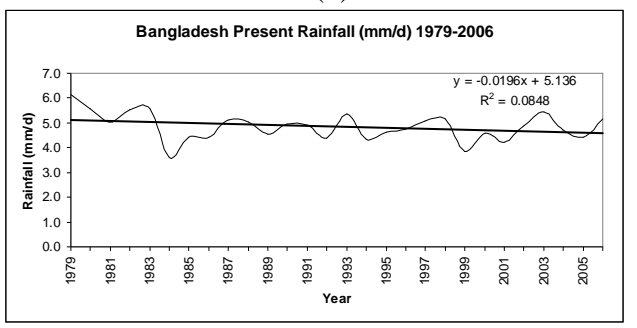

Fig. 6. Present average rainfall of (a) Shapahar \& Porsha, (b) Kalapara, (c) Amtoli, and (d) overall Bangladesh. 


\subsubsection{Near future average rainfall}

Average near future (2015-2034) rainfall of northwestern part (Shapahar and Porsha) shows slightly decreasing trend $(0.66 \mathrm{~mm} / 100$ years $)$. Average rainfall fluctuates, the highest rainfall is $5.33 \mathrm{~mm} /$ day in the year 2025. The lowest pick average rainfall is $3.27 \mathrm{~mm} /$ day in the year 2030 . $\mathrm{R}^{2}$ value is 0.0053 which indicates no significant decrease of average rainfall (Fig. 7a).

In case of southwestern part, present average rainfall shows slightly increasing trend (increases up to $1.5 \mathrm{~mm} / 100$ years). The highest average rainfall of Kalapara is $6.66 \mathrm{~mm} /$ day in the year 2029 and the lowest average rainfall is 2.65 $\mathrm{mm} /$ day in the year 2030. The highest average rainfall of Amtoli is $5.94 \mathrm{~mm} /$ day in the year 2029 and the lowest rainfall is $2.81 \mathrm{~mm}$ in the year 2030. $\mathrm{R}^{2}$ values for Kalapara and Amtoli are 0.0035 and 0.0157 respectively which indicate

(a)

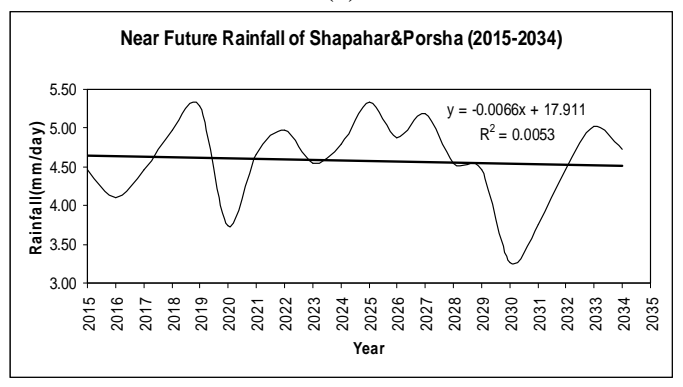

(c)

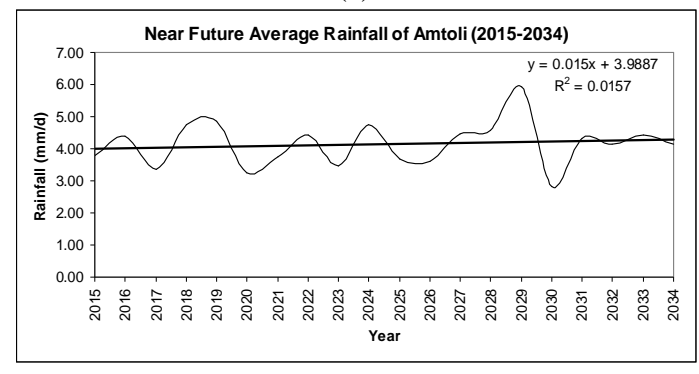

no significant increase of near future average rainfall (Fig. 7b \& 7c).

Present average rainfall of Bangladesh shows slightly increasing trend $(0.69 \mathrm{~mm} / 100$ years $)$. The highest average rainfall is $5.7 \mathrm{~mm} /$ day in the year 2029. The lowest average rainfall is 3.7 in the year 2030. $\mathrm{R}^{2}$ value is 0.0066 which indicates no significant increase of average rainfall (Fig. 7d).

\subsubsection{Future Average Rainfall}

During 2075-2099, average rainfall of northwestern part (Shapahar and Porsha) is expected to show slightly decreasing trend $(0.28$ $\mathrm{mm} / 100$ years). Average rainfall fluctuates, the highest rainfall is $6.50 \mathrm{~mm} /$ day in the year 2089 . The lowest pick average rainfall is expected to be $3.78 \mathrm{~mm} /$ day in the year 2092. $\mathrm{R}^{2}$ value is 0.001 which indicates no significant decrease of average rainfall (Fig. 8a).

(b)

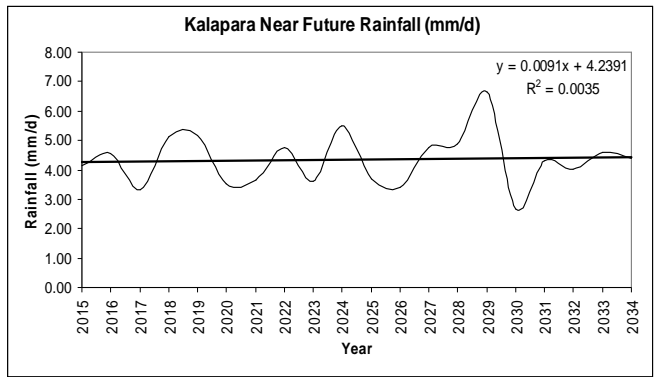

(d)

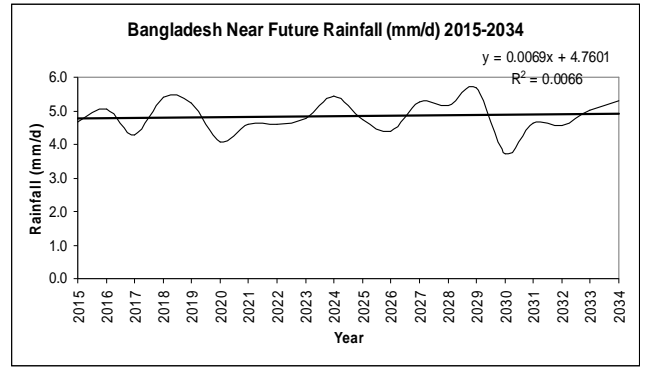

Fig. 7. Near Future Rainfall of (a) Shapahar \& Porsha, (b) Kalapara, (c) Amtoli, and (d) overall Bangladesh. 
(a)

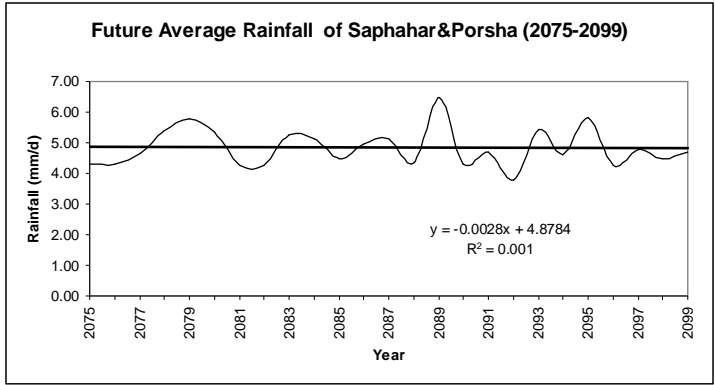

(c)

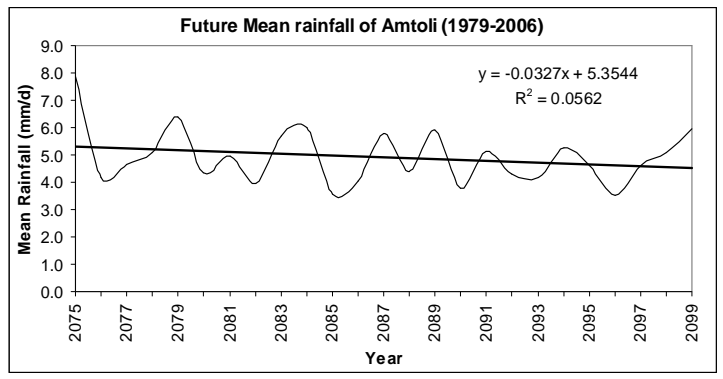

(b)

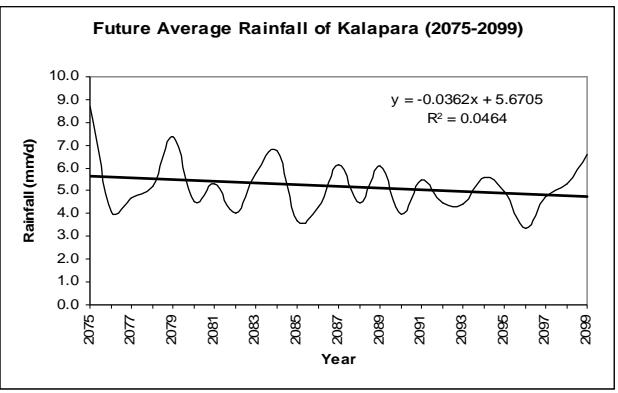

(d)

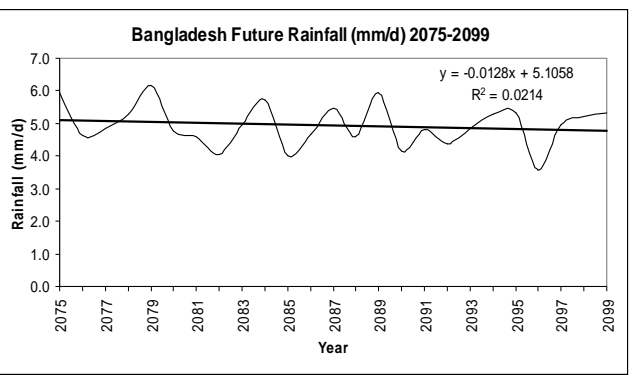

Fig. 8. Future average rainfall of (a) Shapahar and Porsha, (b) Kalapara, (c) Amtoli, and (d) overall Bangladesh.

Regression equations of rainfall situations and corresponding $\mathrm{R}^{2}$ values over the study area are given at Table-2 below:

Table 2. Regression equations of rainfall situations over the study area at a glance.

\begin{tabular}{lllll}
\hline \multicolumn{1}{c}{ Period } & \multicolumn{1}{c}{ Region } & \multicolumn{1}{c}{ Study Area } & Regression Equation & \multicolumn{1}{c}{ R $^{2}$ Value } \\
\hline Present & North West(NW) & Shapahar \& Porsha* & $\mathrm{Y}=-0.003 \mathrm{x}+4.5099$ & 0.0033 \\
& South West(SW) & Kolapara & $\mathrm{Y}=-0.022 \mathrm{x}+4.9743$ & 0.0378 \\
& & Amtoli & $\mathrm{Y}=-0.0192 \mathrm{x}+4.6429$ & 0.0449 \\
& Overall Bangladesh & & $\mathrm{Y}=-0.0196 \mathrm{x}+5.136$ & 0.0848 \\
\hline Near Future & North West(NW) & Shapahar \& Porsha* & $\mathrm{Y}=-0.0066 \mathrm{x}+17.911$ & 0.0053 \\
& South West(SW) & Kolapara & $\mathrm{Y}=0.0091 \mathrm{x}+4.2391$ & 0.0035 \\
& & Amtoli & $\mathrm{Y}=0.015 \mathrm{x}+3.9887$ & 0.0157 \\
& Overall Bangladesh & & $\mathrm{Y}=0.0069 \mathrm{x}+4.7601$ & 0.0066 \\
\hline Future & North West(NW) & Shapahar \& Porsha* & $\mathrm{Y}=-0.0028 \mathrm{x}+4.8784$ & 0.001 \\
& South West(SW) & Kolapara & $\mathrm{Y}=-0.0362 \mathrm{x}+5.6705$ & 0.0464 \\
& & Amtoli & $\mathrm{Y}=-0.0327 \mathrm{x}+5.3544$ & 0.0562 \\
& Overall Bangladesh & & $\mathrm{Y}=-0.0128 \mathrm{x}+5.1058$ & 0.0214 \\
\hline
\end{tabular}

\footnotetext{
* Regression equation \& $\mathrm{R}^{2}$ Value of Shapahar \& Porsa are same as they are in same grid
} 
In case of southwestern part, future average rainfall is expected to show a decreasing trend (decrease up to $3.62 \mathrm{~mm} / 100$ years). The highest average rainfall of Kalapara is $8.69 \mathrm{~mm} /$ day in the year 2075 and the lowest average rainfall is $3.37 \mathrm{~mm} /$ day in the year 2096. The highest average rainfall of Amtoli is expected to be 7.85 $\mathrm{mm} /$ day in the year 2075 and the lowest is 3.51 in the year 2096. $\mathrm{R}^{2}$ values of 0.0464 and 0.0562 , respectively indicate no significant decrease in the present average rainfall (Fig. $8 \mathrm{~b} \& 8 \mathrm{c}$ ).

Future average rainfall of Bangladesh is expected to show slightly decreasing trend (1.28 $\mathrm{mm} / 100$ years). The highest average rainfall is expected to be $6.2 \mathrm{~mm} /$ day in the year 2079 while the lowest $3.6 \mathrm{~mm} / 100$ years in the year 2096. $\mathrm{R}^{2}$ value of 0.0214 indicates no significant decrease of average rainfall (Fig. 8d).

\section{Conclusions}

The present study indicates that the mean temperature for Bangladesh rises slightly, but during near future and future the mean temperature rises is expected to be much more than the present (increases up to $4.34{ }^{\circ} \mathrm{C} / 100$ years). The present, near future and future average rainfalls of Bangladesh was observed to fluctuate, but have shown a decreasing trend (decreases up to $1.96 \mathrm{~mm} / 100$ years). The observation made are based on the data recorded in the Bangladesh Meteorological Department from two areas in northwestern part (Shapahar and Porsha) and two areas in the southwestern part (Kalapara and Amtoli) of Bangladesh. Further studies are needed to know the future climatological situations of other disaster prone areas of Bangladesh.

\section{Acknowledgements}

Authors are grateful to the Meteorological Research Institute (MRI) for providing data of high resolution $(20 \mathrm{~km})$ AOGCM for the study. Thanks are due to Ms. Arjumand Habib, the Director of Bangladesh Meteorological Department (BMD) and SAARC Meteorological Research Centre (SMRC) for providing observational data and computational facility of using AOGCM products respectively.

\section{References}

Ali, A. 1999. Climate Change Impacts and Adaptation Assessment in Bangladesh. Climate Research 12:109-116 pp.

Bengtsson, L. Botzet, M. and Esch, M. 1996. Will greenhouse gas - induced warming over the next 50 years lead to higher frequency and greater intensity of hurricanes? Tellus, 48A: 57-73 pp.

Huq S. Karim, Z. Asaduzzaman, M. and Mahtab, F. (eds.). 1998. Vulnerability and Adaptation to Climate Change for Bangladesh, Kluwer Academic Publishers, Dordrecht, 135 pp.

Houghton, J. T. Ding, Y. Griggs, D. J. Noguer, M. van der Linden, P. J. Dai, X. Maskell, K. and Johnson, C. A. eds., 2001: Climate. Change 2001. The Scientific Basis. Cambridge University Press, 892 pp.

IPCC, 2000: Special Report on Emissions Scenarios. Rogner, H.H. Sankovski, A. Schlesinger, M. Shukla, P. Smith, S. Swart, R. van Rooijen, S. Victor, N. and Dadi, Z. (eds.), A Special Report of Working Grop III of the Intergovernmental Panel on Climate Change, Cambridge University Press, Cambridge, UK.

IPCC, 2001. Climate Change 2001. The scientific Basis. Contribution of Working Group I to the Third Assessment Report of the Intergovernmental Panel on Climate Change In: Houghton, J.T.Y. Ding, D.J. Griggs, M. Noguer, P.J. Vander Linden. X. Dai, K. and Johnson, C. A. (eds.) Cambridge Univ. Press, Cambridge, U.K. and New York, USA.

IPCC, 2007. Climate Change 2007. The physical Science Basis. Contribution of Working Group I to the Fourth Assessment Report of the Intergovernmental Panel on Climate Change. Solomon S, D. Qin, M. Manning, Z. Chen, M. Marquis, K.B. Averyt, M. and Miller, H. L. (eds.), Cambridge University 
Press, Cambridge, United Kingdom and New York, USA, 996 pp.

Islam, M. N. 2009. Rainfall and temperature scenario for Bangladesh. The Open Atmospheric Science Journal, Bentham Open, 3: 93-103 pp.

Islam, M. N. and Uyeda H. 2007. Use of TRMM in determining the climatic characteristics of rainfall over Bangladesh. Remote Sensing Environ. Elsevier Inc., 108(3): 264-76. doi:10.1016/j.rse. 2006.11.011.

Kang, I. S. Jin, K. Wang, B. Lau, K. M. Shukla, J. Krishnamurthy, V. Schubert, S.D. Wailser, D.E. Stern, W.F. Kitoh, A. Meehl, G.A. Kanamitsu, M. Galin, V.Y. Satyan, V. Park, C.K. and Liu, Y. 2002. Intercomparison of the Climatological Variations of Asian Summer Monsoon Precipitation Simulated by 10 GCMs. Clim. Dyn. 19. 383-395 pp.

Kusunoki, S. Yoshimura, J. Yoshimura, H. Noda, A. Oouchi, K. and Mizuta, R. 2006. Change of Baiu rain band in global warming projection by an atmospheric general circulation model with a $20 \mathrm{~km}$ grid size. $J$. Meteor. Soc. Japan, 84: 581-611 pp.
Mizuta, R. K. Oouchi, H. Yoshimura, A. Noda, K, Katayama, S. Yukimoto, M. Hosaka, S. and Nakagawa, M. 2006. 20 km-mesh global climate simulations using JMA-GSM model-Mean Climate States. J. Meteor. Soc. Japan. 84: 165-185 pp.

Oouchi, K., Yoshimura J. Yoshimura H, Mizuta. R, Kusunoki, S, and Noda, A. 2006. Tropical cyclone climatology in a global warming climate as simulated in a $20 \mathrm{~km}$ mesh global atmospheric model frequency and wind intensity analyses. J. Meteor. Soc. Japan. 84, 259-276 pp.

Randall, D. and Pan, D. M. 1993. Implementation of the Arakawa-Schubert cumulus parameterization with a prognostic closure. Meteorol Monoger, 46: 145-150.

Rayner, N.A., Parker, D.E., Horton, E.B., Folland, C.K., lexander, L.V., Rowell, D.P., Kent, E.C.and Kaplan, A. 2003. Global analyses of sea surface temperature, sea ice, and night marine air temperature since the late nineteenth century. J. Geophysic Res. 108:4407, doi:10,1029/2002JD002670.

Wang, B. and Ho, L. 2002. Rainy Season of the Asian-Pacific Summer Monsoon. J. Climate, 15: 386-398 pp. 